\title{
COMPARISON OF SOME POTENTIAL EVAPOTRANSPIRATION METHODS FOR SUMAIL AREA, KURDISTAN REGION OF IRAQ
}

(Received:24.12.2011)

\author{
By \\ M. K. Hassan, J. M.T. Hameed and S. K. Abdul-Karim * \\ Department of Forestry and * Department of Basic Sciences, \\ University of Dohuk, Kurdistan Region, Iraq
}

\begin{abstract}
Potential evapotranspiration (PET) was calculated in monthly basis for the Sumail area using FAO56 Penman-Monteith and several other methods. PET calculated by Penman-Monteith method was then predicted using PET calculated by each of the other methods and pan measurement employing three mathematical equations. Among them the simple linear equation turned out to be the favorite. All the considered methods had very good predictive capability. Hargreaves method, however, was the most accurate with and without calibration.
\end{abstract}

Key words: FAO-56 Penman-Monteith, kurdistan Region of Iraq, potential evapotranspiration.

\section{INTRODUCTION}

Evapotranspiration (ET) is an important component of the hydrological cycle and a necessary parameter for irrigation scheduling. It is defined as the loss of water to the atmosphere by the combine processes of evaporation from soil and plant surfaces and transpiration from plants (Allen et al., 1998). Many factors affect ET, including; weather parameters such as solar radiation, air temperature, humidity and wind speed; crop factors such as crop type, variety, density, stage of growth and management; and environmental conditions such as soil conditions, salinity, fertility, crop diseases and pests (Allen et al., 1998).

According to Kite (2000) about $65 \%$ of the precipitation on the earth's surface evaporates back into the atmosphere. In the Southeastern part of the USA, about 50 to 80 percent of precipitation is returned to the atmosphere as evapotranspiration (Lu et al., 2005).

Potential Evapotranspiration (PET) can be generally defined as the amount of water that could evaporate and transpire from a vegetated landscape without restrictions other than the atmospheric demand (Jensen et al., 1990). The concept of potential evapotranspiration (PET) provides a convenient index to estimate the maximum water loss to the atmosphere. Potential evapotranspiration (PET) is also used as an index to represent the available environmental energies and ecosystem productivity (Currie, 1991). Estimates of PET are necessary in many of the rainfall runoff and ecosystem models that are used in global change studies (Hay and McCabe, 2002). Generally potential evapotranspiration is estimated by theoretical or empirical equations or derived simply by multiplying standard pan evaporation data by a coefficient (Grismer et al., 2002).

There are many methods or models available to estimate PET, but these give inconsistent values due to their different assumptions and input data requirements or because they are often developed for specific climatic regions (Grismer et al., 2002). Previous studies at multiple scales have suggested that different PET methods may give significantly different results (Feder et al., 1996). In general, most practical approaches for estimating PET are based on one or more climatic variable such as air temperature, solar radiation, wind speed and relative humidity, or on some measurements related to these variables like pan evaporation. In connection with, various methods are available for estimating PET involving equations ranging from the most complex energy balance method requiring detailed climatologic data to simpler methods requiring less data (Allen, et al., 1989). Among them the FAO-56 based on the Penman- Monteith (PM) method is currently used and can be considered as a standard method (Alkaeed et al., 2006). However, the major 
drawback of this method is its requirements for data regarding air temperature, relative humidity, wind speed, and solar radiation which could not be easily available in many meteorological stations (Irmak et al., 2003). Additionally, it also uses a complicated unit conversions and lengthy calculation (Wu, 1997). On the other hand, there are simple methods based on either temperature alone, such as, the Thornthwaite (1948), Blaney and Criddle (1950), Kharrufa (1985), and Hargreaves and Samani (1985), or on solar radiation alone, such as, Makkink (1957), Priestly and Taylor (1972) and Hargreaves (1975). This work aims at quantifying PET in the study area using several empirical methods and quantifying the performance of these methods, and developing calibrated equation for each of the evaluated method.

The pan measurement method uses evaporation to estimate PET and is another common method especially in Asian countries (Chen et al., 2005). Pans provide a measurement of the integrated effect of radiation, wind speed, temperature and humidity on the evaporation from an open water surface. The pan has proved its practical value and has been widely used to estimate PET (Chen et al., 2005). Applying empirical coefficient to relate pan evaporation to PET for periods of 10 days or longer may be warranted (Allen et al., 1998). Investigations on potential evapotranspiration (PET) in the study area and its surrounding were covered by Kettaneh (1974), Ahmed and Jasim (2002), and Aqrawi (2003).

\section{MATERIALS}

The study area is located to the west of Dohuk City, Iraqi Kurdistan Region between latitude $36^{\circ} 80^{\prime}-36^{0} 90^{\prime} \mathrm{N}$, and longitude $42^{0} 69^{\prime}$ $42^{0} 93^{\prime} \mathrm{E}$ (Figure 1). The climate of the area is similar to the Mediterranean climatic conditions. It is characterized by rainy cold winter and dry hot summer. The daily and monthly meteorological data were obtained from the Agro-meteorological Station of the College of Agriculture, Dohuk University in Sumail area (latitude $36^{\circ} 51^{\prime} 37^{\prime \prime} \mathrm{N}$, longitude $42^{0} 56^{\prime} 30^{\prime \prime} \mathrm{E}$ ) for the period from January, 1997 to December, 2006. The data included mean air temperature, mean maximum and minimum temperature, mean sunshine duration, mean wind speed and humidity, as well as the monthly water evaporation in a pan class A.

According to the recorded data of the meteorological station of the College of Agriculture, the average annual precipitation for the aforementioned period was $438.3 \mathrm{~mm} \mathrm{yr}^{-1}$, more than $55 \%$ of which occurred during January to March. The mean minimum and maximum monthly air temperature ranged from $20.5{ }^{\circ} \mathrm{C}$ to $39.6{ }^{\circ} \mathrm{C}$ in summer and $3.3{ }^{\circ} \mathrm{C}$ to $13.8^{\circ} \mathrm{C}$ in winter, respectively. The monthly mean temperature in summer was $30.1{ }^{\circ} \mathrm{C}$ and in winter was $8.6{ }^{\circ} \mathrm{C}$ with an annual average of $18.3{ }^{\circ} \mathrm{C}$, while daily mean minimum and maximum temperature in summer were $20.9{ }^{\circ} \mathrm{C}$ and $40{ }^{\circ} \mathrm{C}$ and in winter were $2.7{ }^{\circ} \mathrm{C}$ and $12.6{ }^{\circ} \mathrm{C}$.,respectively. Monthly mean minimum and maximum relative humidity were $28 \%$ and $64 \%$, respectively with an annual average of $45 \%$. The observed maximum, minimum and average monthly wind speeds in the considered period were $2.2 \mathrm{~ms}^{-1}, 1.4 \mathrm{~ms}^{-1}$ and 1.8 , $\mathrm{ms}^{-1}$ respectively.

\section{METHDODS}

The selected seven PET methods and Pan Measurement in this comparative study are commonly used and need fewer input requirements than the PM method. They include four temperature based methods, which were Thornthwaite (1948), Blaney and Criddle (1950), Kharrufa (1985), and Hargreaves and Samani (1985), and three radiation based methods, which were Makkink (1957), Priestley and Taylor (1972), Hargreaves (1975), and Pan measurement (Table 1).

The following is a description of the equation used by each method;

\section{FAO-56 Penman and Monteith method.}

According to Allen et al. (1998), the FAO-56

Penman-Monteith Method for PET estimation $\left(\mathrm{mm} \mathrm{d}^{-1}\right)$ can be expressed as:

$$
\mathrm{PET}=\frac{0.408 \Delta\left(\mathrm{R}_{\mathrm{n}}-\mathrm{G}\right)+\gamma(900 / \mathrm{T}+273) \mathrm{U}_{2}\left(\mathrm{e}_{\mathrm{s}}-\mathrm{e}_{\mathrm{a}}\right)}{\Delta+\gamma\left(1+0.34 \mathrm{U}_{2}\right)}
$$

Where PET is potential evapotranspiration $\left(\mathrm{mm} \mathrm{d}^{-1}\right), \mathrm{R}_{\mathrm{n}}$ is net radiation at the crop surface $\left[\mathrm{MJ} \mathrm{m}^{-2} \mathrm{~d}^{-1}\right] \mathrm{G}$ is soil heat flux density $\left(\mathrm{MJ} \mathrm{m}^{-2} \mathrm{~d}^{-}\right.$ $\left.{ }^{1}\right), \mathrm{T}$ is mean daily air temperature at $2 \mathrm{~m}$ height $\left({ }^{\circ} \mathrm{C}\right), \mathrm{U}_{2}$ is wind speed at $2 \mathrm{~m}$ height $\left(\mathrm{m} \mathrm{s}^{-1}\right) \mathrm{e}_{\mathrm{s}}$ is saturation vapor pressure $(\mathrm{kPa}), \mathrm{e}_{\mathrm{a}}$ is actual vapor pressure $(\mathrm{kPa}), \Delta$ is slope vapor pressure curve $\left(\mathrm{kPa}{ }^{\circ} \mathrm{C}^{-1}\right) \gamma$ is psychometric constant $\left(\mathrm{kPa}^{\circ} \mathrm{C}^{-1}\right)$, and $\left(e_{s}-e_{a}\right)$ is saturation vapor pressure deficit $(\mathrm{kPa})$. It is the difference between the saturation $\left(e_{s}\right)$ and actual vapor pressure $\left(e_{a}\right)$ for the period of a day. The saturation vapor pressure $\left(e_{s}\right)$ per day is computed as the mean between the saturation vapor pressure at the daily maximum and minimum air temperatures: 
Table (1): Monthly Variable and Parameters Required by Each PET Method:

\begin{tabular}{|c|c|c|c|c|c|c|}
\hline $\begin{array}{l}\text { Variables } \\
\text { Methods }\end{array}$ & Temperature & Radiation & Humidity & Wind Speed & $\begin{array}{l}\text { Number of } \\
\text { daylight } \\
\text { Hours }\end{array}$ & $\begin{array}{l}\text { Saturated } \\
\text { vapor } \\
\text { pressure }\end{array}$ \\
\hline FAO-56 PM & Mean Daily & Net Radiation & $\begin{array}{l}\text { Mean } \\
\text { Daily }\end{array}$ & Mean Daily & - & Mean Daily \\
\hline Thornthwaite & Mean Monthly & 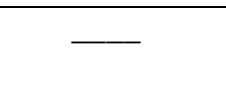 & . & - & $\begin{array}{l}\text { Daytime } \\
\text { length }\end{array}$ & $\ldots$ \\
\hline Blaney\&Criddle & Mean Daily & 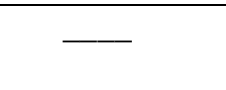 & - & - & $\begin{array}{l}\text { Daytime } \\
\text { length }\end{array}$ & - \\
\hline Kharrufa & Mean Daily & - & 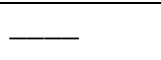 & - & - & - \\
\hline $\begin{array}{l}\text { Hargreaves\& } \\
\text { Samani }\end{array}$ & $\begin{array}{c}\text { Daily } \\
\text { maximum } \\
\& \text { minimum }\end{array}$ & $\begin{array}{c}\text { Extraterrestrial } \\
\text { Radiation }\end{array}$ & - & - & - & - \\
\hline Makkink & Mean Daily & $\begin{array}{c}\text { Solar } \\
\text { Radiation }\end{array}$ & 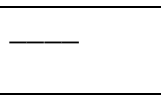 & $\ldots$ & - & - \\
\hline Priestly\&Taylor & Mean Daily & Net Radiation & - & - & - & - \\
\hline \multirow[t]{2}{*}{ Hargreaves } & Mean Daily & $\begin{array}{c}\text { Solar } \\
\text { Radiation }\end{array}$ & . & - & - & - \\
\hline & Mean Daily & $\ldots$ & $\begin{array}{l}\text { Mean } \\
\text { Daily }\end{array}$ & Mean Daily & 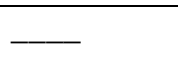 & - \\
\hline
\end{tabular}

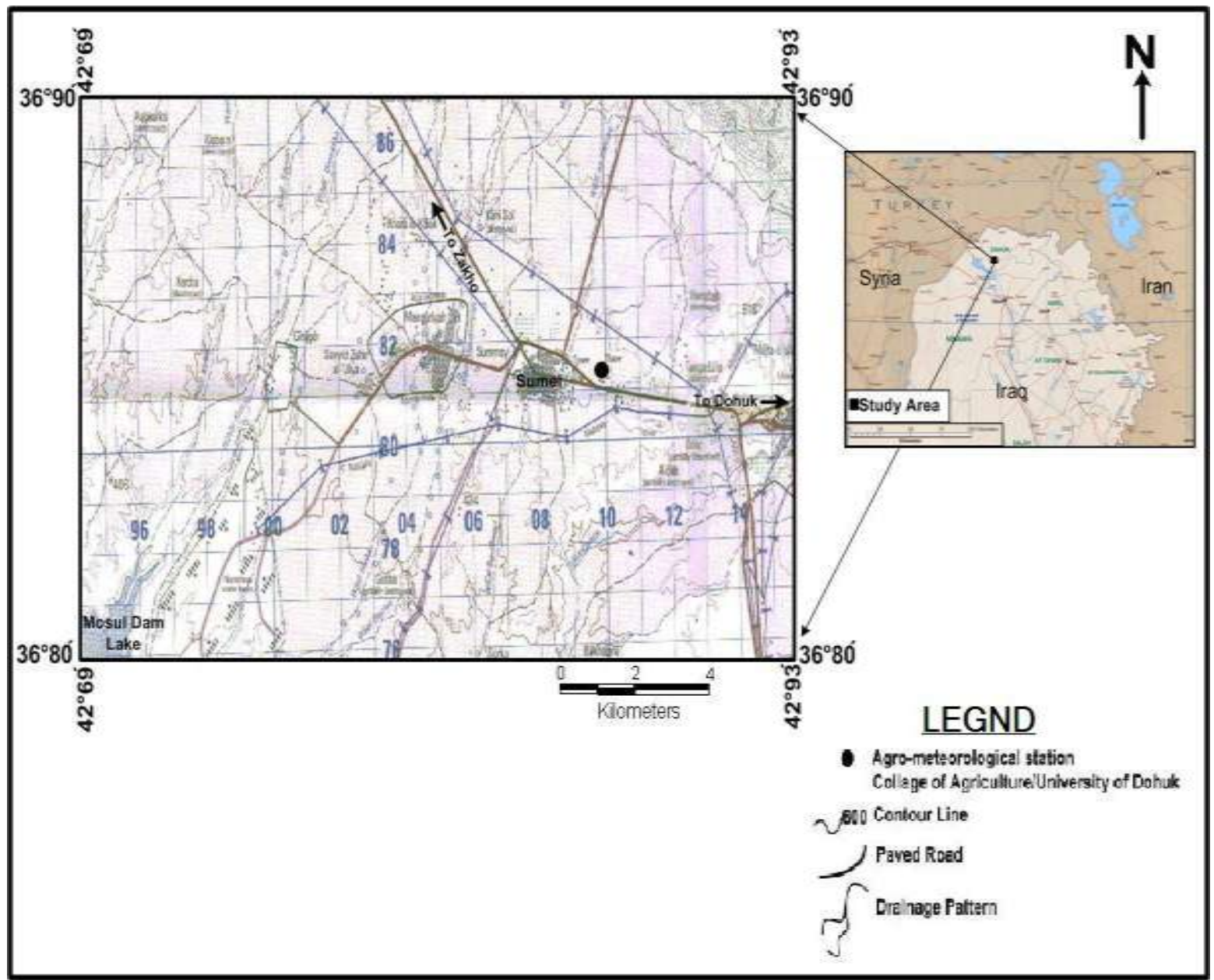

Fig. (1): Location map of the study area. 


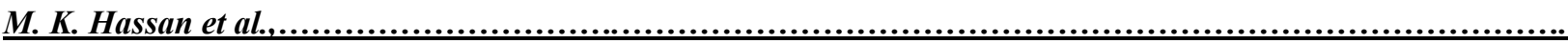

Table (2): Descriptive Statistics for PET Calculated by Each Method.

\begin{tabular}{|l|l|l|l|l|l|}
\hline Method & Mean & St. deviation & Minimum & Maximum & $\begin{array}{l}\text { Coefficient } \\
\text { Of } \\
\text { Variation }\end{array}$ \\
\hline $\begin{array}{l}\text { FAO-56 Penman- } \\
\text { Monteith }\end{array}$ & 117.1 & 70.1 & 25.2 & 243.5 & 59.8 \\
\hline Thornthwaite & 78.8 & 62.3 & 40 & 240.4 & 79.1 \\
\hline Blaney-Criddle & 135 & 87.1 & 29.5 & 328.4 & 64.5 \\
\hline Kharrufa & 146 & 98.8 & 20.3 & 351.8 & 67.6 \\
\hline $\begin{array}{l}\text { Hargreaves- } \\
\text { Samani }\end{array}$ & 327.5 & 194.9 & 74.2 & 665.4 & 59.5 \\
\hline $\begin{array}{l}\text { Makkink } \\
\text { Priestley- } \\
\text { Taylor }\end{array}$ & 94.3 & 51.3 & 26.9 & 191.3 & 54.4 \\
\hline $\begin{array}{l}\text { Hargreaves } \\
\text { Pan A } \\
\text { measurement }\end{array}$ & 118.2 & 72.4 & 28.1 & 259.1 & 61.2 \\
\hline
\end{tabular}

Table (3): Model coefficients and adjusted $\mathbf{R}^{2}$ for the different methods.

\begin{tabular}{|c|c|c|c|c|c|}
\hline Methods & Models & Bo & B1 & B2 & $\begin{array}{c}\text { Adjusted } \\
\mathbf{R}^{2}\end{array}$ \\
\hline Thornthwaite & $\begin{array}{c}\text { Linear } \\
\text { Double-log } \\
\text { Polynomial }\end{array}$ & $\begin{array}{c}30.5 \\
2.159 \\
19.54\end{array}$ & $\begin{array}{l}1.091 \\
0.610 \\
1.516\end{array}$ & -0.0022 & $\begin{array}{l}0.952 \\
0.914 \\
0.964\end{array}$ \\
\hline $\begin{array}{c}\text { Blaney and } \\
\text { Criddle }\end{array}$ & $\begin{array}{c}\text { Linear } \\
\text { Double-log } \\
\text { Polynomial }\end{array}$ & $\begin{array}{c}10.4 \\
0.228 \\
-1.94\end{array}$ & $\begin{array}{l}0.789 \\
0.927 \\
1.033\end{array}$ & -0.0008 & $\begin{array}{c}0.966 \\
0.965 \\
0.97\end{array}$ \\
\hline Kharrufa & $\begin{array}{c}\text { Linear } \\
\text { Double-log } \\
\text { Polynomial }\end{array}$ & $\begin{array}{c}15.6 \\
0.762 \\
10.734\end{array}$ & $\begin{array}{l}0.691 \\
0.808 \\
0.789 \\
\end{array}$ & -0.0003 & $\begin{array}{l}0.966 \\
0.957 \\
0.966\end{array}$ \\
\hline $\begin{array}{l}\text { Hargreaves } \\
\text { and } \\
\text { Samani }\end{array}$ & $\begin{array}{c}\text { Linear } \\
\text { Double-log } \\
\text { Polynomial }\end{array}$ & $\begin{array}{c}1.1 \\
-1.023 \\
-1.105\end{array}$ & $\begin{array}{l}0.353 \\
0.998 \\
0.372\end{array}$ & -0.00025 & $\begin{array}{l}0.973 \\
0.979 \\
0.973\end{array}$ \\
\hline Makkink & $\begin{array}{c}\text { Linear } \\
\text { Double-log } \\
\text { Polynomial }\end{array}$ & $\begin{array}{c}-10.4 \\
-0.397 \\
-8.2\end{array}$ & $\begin{array}{l}1.353 \\
1.13 \\
1.29\end{array}$ & 0.0003 & $\begin{array}{c}0.98 \\
0.979 \\
0.98\end{array}$ \\
\hline $\begin{array}{c}\text { Priestley and } \\
\text { Taylor }\end{array}$ & $\begin{array}{c}\text { Linear } \\
\text { Double-log } \\
\text { Polynomial }\end{array}$ & $\begin{array}{c}10.6 \\
0.828 \\
11.2\end{array}$ & $\begin{array}{l}1.21 \\
0.866 \\
1.101\end{array}$ & 0.00049 & $\begin{array}{c}0.942 \\
0.934 \\
0.94\end{array}$ \\
\hline Hargreaves & $\begin{array}{c}\text { Linear } \\
\text { Double-log } \\
\text { Polynomial }\end{array}$ & $\begin{array}{c}3.5 \\
0.019 \\
-4.6\end{array}$ & $\begin{array}{l}0.96 \\
0.994 \\
1.144\end{array}$ & 0.0007 & $\begin{array}{l}0.985 \\
0.984 \\
0.987\end{array}$ \\
\hline $\begin{array}{c}\text { Pan A } \\
\text { measurment }\end{array}$ & $\begin{array}{c}\text { Linear } \\
\text { Double-log } \\
\text { Polynomial }\end{array}$ & $\begin{array}{c}16.8 \\
0.366 \\
6.35\end{array}$ & $\begin{array}{c}0.546 \\
0.849 \\
0.71\end{array}$ & 0.00039 & $\begin{array}{l}0.962 \\
0.962 \\
0.965\end{array}$ \\
\hline
\end{tabular}




$$
\mathrm{e}_{\mathrm{s}}=\frac{\mathrm{e}^{\circ}\left(\mathrm{T}_{\max }\right)+\mathrm{e}^{\circ}\left(\mathrm{T}_{\text {min }}\right)}{2}
$$

The actual vapor pressure $\left(e_{a}\right)$ was calculated from the relative humidity

$$
\mathrm{e}_{a}=\frac{\mathrm{e}^{\circ}\left(\mathrm{T}_{\text {min }}\right) \frac{R \mathrm{RH}_{\text {max }}}{100}+\mathrm{e}^{\circ}\left(\mathrm{T}_{\max }\right) \frac{R \mathrm{RH}_{\text {min }}}{100}}{2}
$$

where $\mathrm{e}_{\mathrm{a}}$ actual vapor pressure $[\mathrm{kPa}], \mathrm{e}^{\circ}\left(\mathrm{T}_{\min }\right)$ saturation vapor pressure at minimum temperature $[\mathrm{kPa}], \mathrm{e}^{\circ}\left(\mathrm{T}_{\max }\right)$ saturation vapor pressure at maximum temperature $[\mathrm{kPa}], \mathrm{RH}_{\max }$ maximum relative humidity [\%], $\mathrm{RH}_{\min }$ minimum relative humidity [\%].

Saturation vapor pressure at any given temperature $\left(\mathrm{e}^{\circ}(\mathrm{T})\right)$ is calculated from the air temperature using the following relationship:

$$
e^{\circ}(T)=0.6108 \mathrm{e} \times p\left[\frac{17.27 T}{T+237.3}\right]
$$

where $\mathrm{e}^{\circ}(\mathrm{T})$ saturation vapor pressure at the air temperature $\mathrm{T}[\mathrm{kPa}], \mathrm{T}$ air temperature $\left[{ }^{\circ} \mathrm{C}\right]$, $\exp [.]$.2.7183 (base of natural logarithm) raised to the power [..]. PET of each month was then obtained by summing up the PET of the days of that month. Same procedure was followed to calculate the monthly PET by other methods except for Thornthwaite, Blaney\&Criddle, and Kharrufa Methods.

\section{Thornthwaite Method}

Thornthwaite (1948) correlated the mean monthly temperature with PET using the following formula

$$
\text { PET }=16 * d(10 \mathrm{~T} / \mathrm{I})^{\mathrm{a}}
$$

Where PET is the monthly potential evapotranspiration $\left(\mathrm{mm} \mathrm{d}^{-1}\right), \mathrm{d}$ is the monthly correction factor which depend on latitude, $\mathrm{T}$ is the monthly mean air temperature $\left({ }^{\circ} \mathrm{C}\right)$, I is the annual thermal index, which is computed from the monthly thermal indices .

$$
\mathrm{I}=\sum_{\mathrm{J}=1}^{12} \mathrm{i}_{\mathrm{j}}
$$

Where $i_{j}=\left(T_{j} / 5\right)^{1.514} ; T_{j}$ is the mean air temperature in $\mathrm{C}^{\mathrm{o}}$ for month $\mathrm{j} ; \mathrm{j}=1, \ldots . ., 12$; and a $=0.492+\left(179 * 10^{-4}\right) \mathrm{I}-\left(771 * 10^{-7}\right) \mathrm{I}^{2}+\left(675^{*} 10^{-9}\right)$ $\mathrm{I}^{3}$. In general, the Thornthwaite method underestimates the PET in the arid area, while it overestimates PET in the humid area (Alkaeed et al., 2006).

\section{Blaney and Criddle Method}

Aqrawi (2003) stated that Blaney and Criddle (1950) method is one of the most popular equations. This method has the following form:

$\mathrm{PET}=\mathrm{KP}(0.46 \mathrm{~T}+8.13)$

Where $\mathrm{K}$ is correction factor which is equal to $(0.0311 \mathrm{~T}+0.24), \mathrm{T}$ is the mean monthly temperature $\left({ }^{\circ} \mathrm{C}\right)$ and $\mathrm{P}$ is mean monthly percentage of annual daytime hours.

\section{Kharrufa Method}

Kharrufa (1985) derived a simple and flexible equation to calculate PET values and it is expressed as:

$$
\text { PET }=0.34 \mathrm{PT}^{1.3}
$$

Where PET, P and T are as defined before.

\section{Hargreaves and Samani Method}

The Hargreaves and Samani (1985) method is expressed as:

PET $=0.0023(T+17.8) \sqrt{ }($ Tmax.-Tmin. $)$ Ra (8)

Where PET is daily potential evapotranspiration $(\mathrm{mm}), \mathrm{T}$ is the daily mean air temperature $\left({ }^{\circ} \mathrm{C}\right)$, Tmax. is daily maximum air temperature $\left({ }^{\circ} \mathrm{C}\right)$, Tmin. is daily minimum air temperature $\left({ }^{\circ} \mathrm{C}\right)$ and $\mathrm{Ra}$ is the extra terrestrial radiation $\left(\mathrm{MJ} \mathrm{m}^{-2} \mathrm{~d}^{-1}\right)$. The mean air temperature in the Hargreaves and samani method is calculated as an average of $\mathrm{T}_{\max }$ and $\mathrm{T}_{\text {min }}$ and $\mathrm{Ra}$ is computed from information on location of the site and time of the year. Therefore, air temperature is the only parameter that needs to be measured continuously in order to use this method (Temesgen et al., 2005).

\section{Makkink Method}

This method is expressed by the following equation,

$$
\mathrm{PET}=0.61(\Delta / \Delta+\gamma) *\left(\mathrm{R}_{\mathrm{s}} / \lambda\right)(9)
$$

Where PET is the daily potential evapotranspiration $\left(\mathrm{mm} \mathrm{d}^{-1}\right), \Delta$ is the slope of the saturation vapor pressure temperature curve $(\mathrm{kPa}$ $\left./{ }^{\circ} \mathrm{C}\right), \gamma$ is psychometric constant $\left(\mathrm{kPa} /{ }^{\circ} \mathrm{C}\right), \mathrm{R}_{\mathrm{s}}$ is the total solar radiation ( $\mathrm{cal} \mathrm{m}^{-2} \mathrm{~d}^{-1}$ ); and $\lambda$ is the latent heat of vaporization $\left(\mathrm{calg}^{-1}\right)$ and $\lambda=0.501$ $0.002361 \mathrm{~T}$, where $\mathrm{T}$ is the daily mean air temperature $\left({ }^{\circ} \mathrm{C}\right)$.

\section{Priestley and Taylor Method}

This method is based on the following equation,

$$
\mathrm{PET}=1.26(\Delta / \Delta+\gamma) *\left(\mathrm{R}_{\mathrm{n}} / \lambda\right) \quad(10)
$$

Where PET is the daily potential evapotranspiration $\left(\mathrm{mm} \mathrm{d}^{-1}\right), \Delta$ is the slope of the saturation vapor pressure temperature curve $\left(\mathrm{kPa} /{ }^{\circ} \mathrm{C}\right) ; \gamma$ is psychometric constant $\left(\mathrm{kPa}^{\circ} \mathrm{C}^{-1}\right) ; \mathrm{R}_{\mathrm{n}}$ is the net radiation $\left(\mathrm{MJ} \mathrm{m}^{-2} \mathrm{~d}^{-1}\right)$; and $\lambda$ is the latent heat of vaporization $\left(\mathrm{calg}^{-1}\right)$.

\section{Hargreaves Method}

This method estimates PET using the following model

$$
\mathrm{PET}=0.0135(\mathrm{~T}+17.8)\left(\mathrm{R}_{\mathrm{s}} / \lambda\right) \quad(11)
$$

Where PET is daily potential evapotranspiration $\left(\mathrm{mm} \mathrm{d}^{-1}\right)$; $\mathrm{T}$ is the daily mean air temperature $\left({ }^{\circ} \mathrm{C}\right)$, $\mathrm{R}_{\mathrm{s}}$ is the total solar radiation $\left(\mathrm{cal} \mathrm{m}^{-2} \mathrm{~d}^{-1}\right), \lambda$ is the latent heat of vaporization $\left(\mathrm{cal} \mathrm{g}^{-1}\right)$.

Evaporation pans provide a measurement of the combined effect of temperature, humidity, 
wind speed and sunshine on the potential evapotranspiration (PET). Different types of evaporation pans are being used. The best known pan is the class A evaporation pan (circular pan) which was used in the study area and the sunken Colorado pan (square pan). The pan evaporation is related to the potential evapotranspiration by an empirically derived pan coefficient (Allen et al., 1998).

$$
\mathrm{PET}=\mathrm{Kp} \text { Epan }
$$

Where $\mathrm{Kp}$ is pan coefficient, Epan is pan evaporation $\left(\mathrm{mm} \mathrm{d}^{-1}\right)$ and PET is $\left(\mathrm{mm} \mathrm{d}^{-1}\right)$. In this work, data of pan evaporation were used without multiplying by pan coefficient.

To evaluate the accuracy of each method adopted in this work, monthly PET calculated by PM method was drawn along with PET estimated by each of the other methods. One of the most important considerations in establishing a simple method other than the standard method such as the PM method is the possibility of unavailability and unreliable weather data measurement and collections. In general, a setup of the devices for the meteorological measurement at the remote areas and at a given location is difficult. Hence, accuracy of data, specifically the data of advanced input variables such as humidity and radiation would be low. Therefore, it is justifiable to develop equations that can accurately measure PET using simple and easy collected meteorological data. For this purpose, scatter diagrams were drawn to reveal the pattern of relationships between monthly PET estimated by FAO-56 Penman-Monteith method, on one hand, and monthly PET estimated by each of the other methods (Fig. 2). Then regression analysis was employed to predict PET calculated by PenmanMonteith method using corresponding data estimated by each of the other methods. For this purpose, three mathematical equations were selected. Simple linear equation, double log function and second degree polynomial equation were tested using SAS package (1989). Since prediction is the main purpose of developing these equations, adjusted coefficient of determination $\left(\square^{2}\right)$ was used to evaluate the predictive capability of each model. Finally, calibrated equations were developed for each of the seven methods and Pan Measurement.

\section{RESULTS AND DISCUSSION}

Table (2) describes the values of monthly PET calculated by each method. The lowest mean PET was estimated by Thornthwaite $(78.8 \mathrm{~mm})$ and the highest was estimated by Hargreaves and
Samani equation (327.5). The lowest coefficient of variation (C.V.) was associated with the estimate of Makkink method and the highest was associated with the estimate of Thornthwaite method. The mean and C.V. for PenmanMonteith method were 117 and 59.8, respectively. Since PM method is, by far, the most accurate method, it was taken as a standard to evaluate other methods. Table (2) reveals that Hargreaves method is the most accurate one compared with other considered method because the mean, minimum, maximum, standard deviation and C.V. of this method had values very close to their corresponding values of Penman-Monteith method.

Figure (2) contrast monthly PET over time estimated by PM method (dark line) with PET estimated by each of the other method and by pan evaporation measurement (light line). These graphs reveal that the tested methods varied in accuracy in estimating PET in the study region. Again, Hargreaves method was the most accurate since its line graph was the closest to PM line graph (Figure 2h). Figure (2a) shows that Thornthwaite method underestimated PET at all levels of PET compared with PET estimated by PM method. This is compatible with the founding of Alkaeed et al. (2006). Figure (2b) and (2c) demonstrate that Blaney and Criddle method and Kharrufa method tend to overestimate PET at high level of PET and relatively accurate at other levels. Figure (2d) reveals that Hargreaves and Samani method tends to severely overestimated PET in the study area. Figure (2e) shows that evaporation from pan was close to PET at low levels of PET while it considerably overestimatedPET at high level of PET. With respect to methods based on radiation, Makkink method behaved similarly to Kharrufa and Blaney and Criddle methods (Figure 2f), while Priestley and Taylor methods were similar to Thornthwaite method (Figure 2g). As stated earlier, Figure (2h) shows that Hargreaves method was the most accurate one since its line plot match the line plot of PM method except for high level of PET where it slightly over estimated PET. Therefore, Hargreaves equation is preferred to be used to estimate PET if no calibration is applied.

The scatter diagrams in Figure (3) show the pattern of relationship between PET of PM method, on one hand, and PET estimated by each of other method and pan evaporation on the other hand. This Figure shows existence of strong relationships between the PET of corresponding pairs of methods. Therefore, SAS package was 


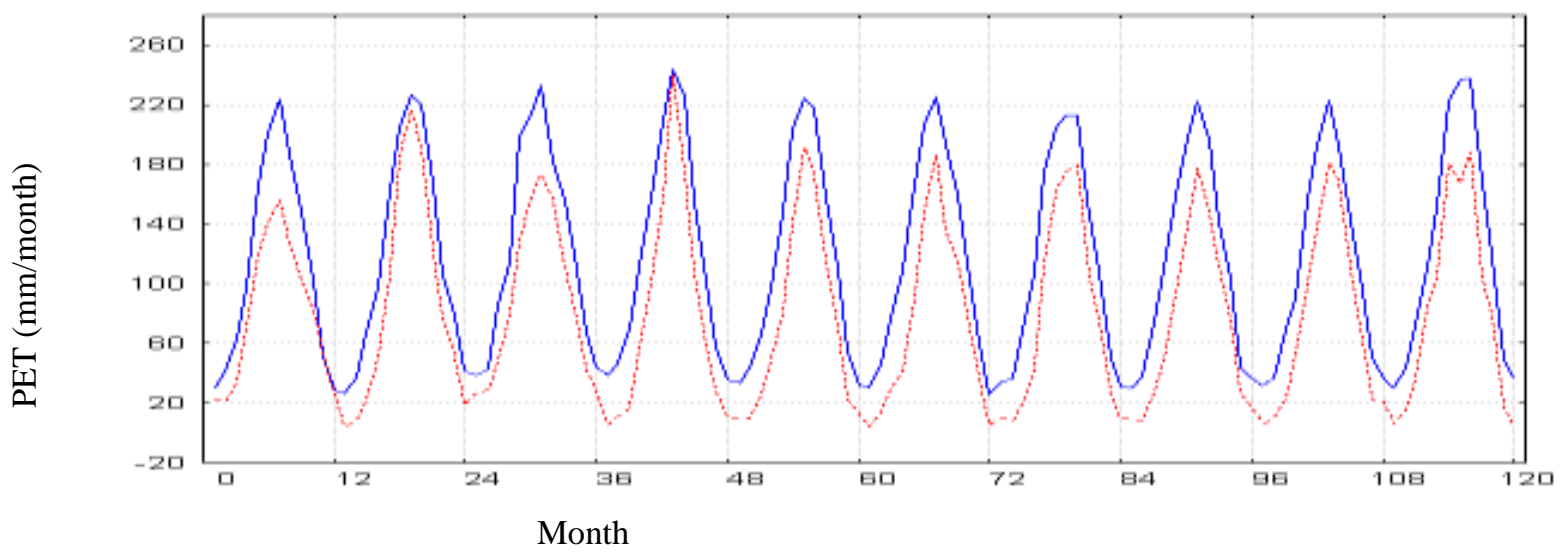

a. Thornthwaite versus Penman-Monteith.

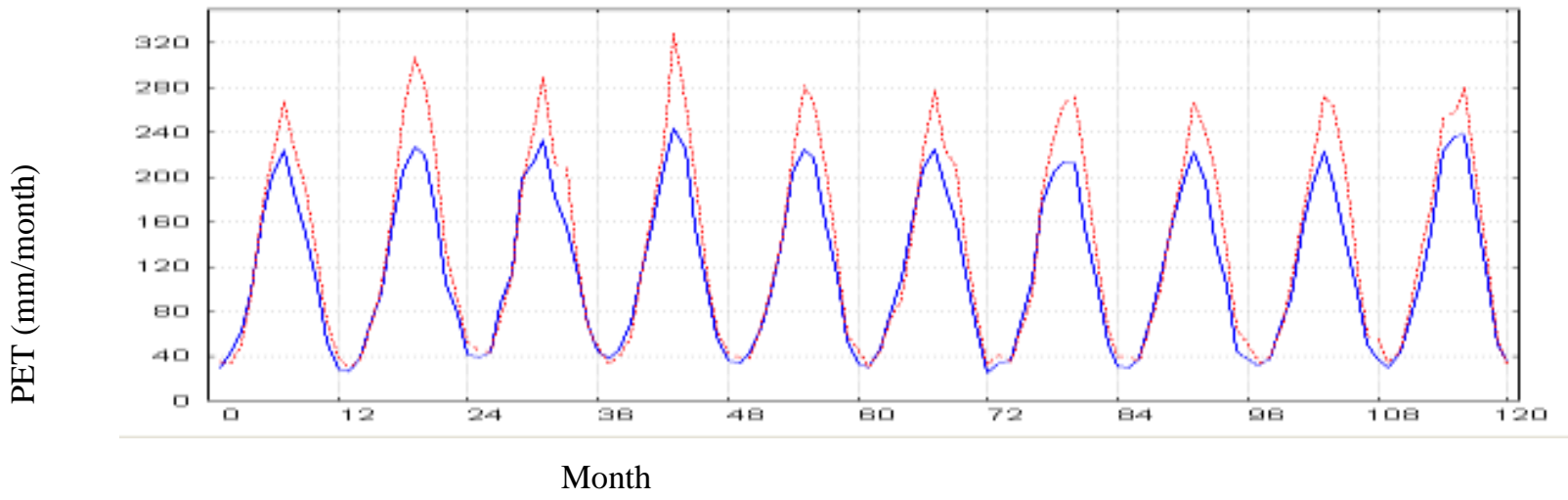

b. Blaney and Criddle versus Penman-Monteith.

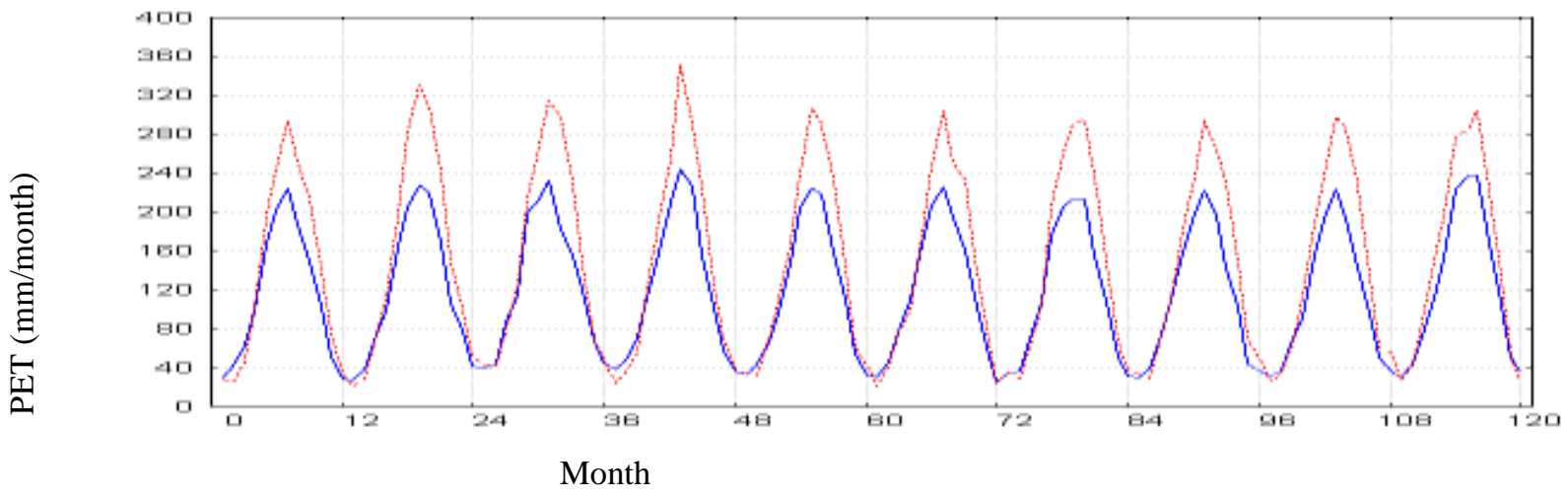

c. Kharrufa versus Penman-Monteith.

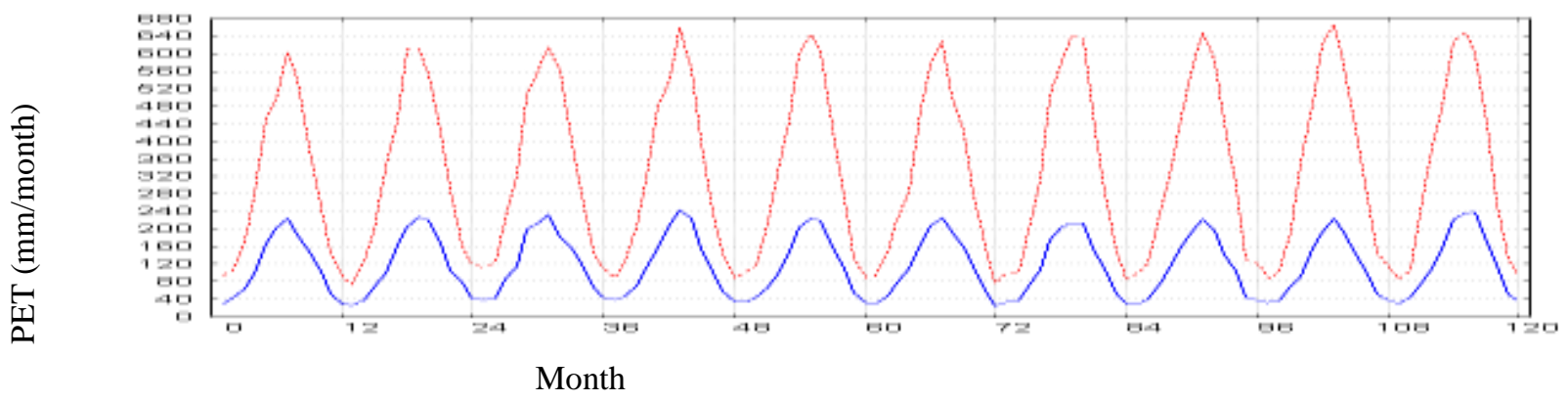

d. Hargreaves and Samani versus Penman-Monteith. 


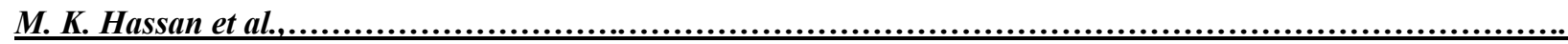

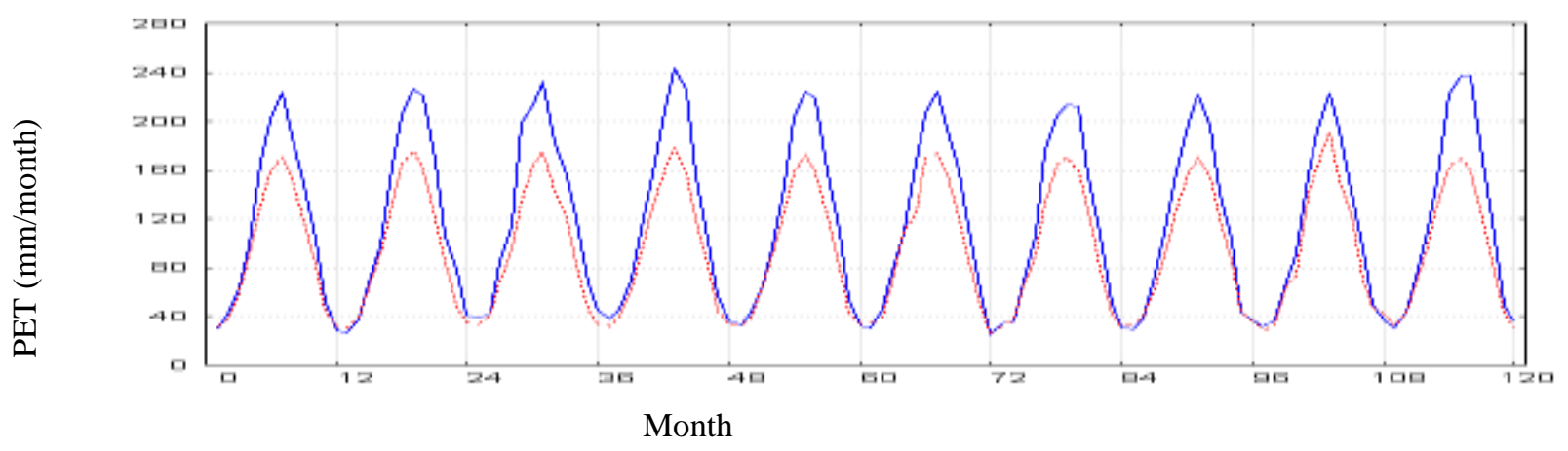

e. Makkink versus Penman-Monteith.

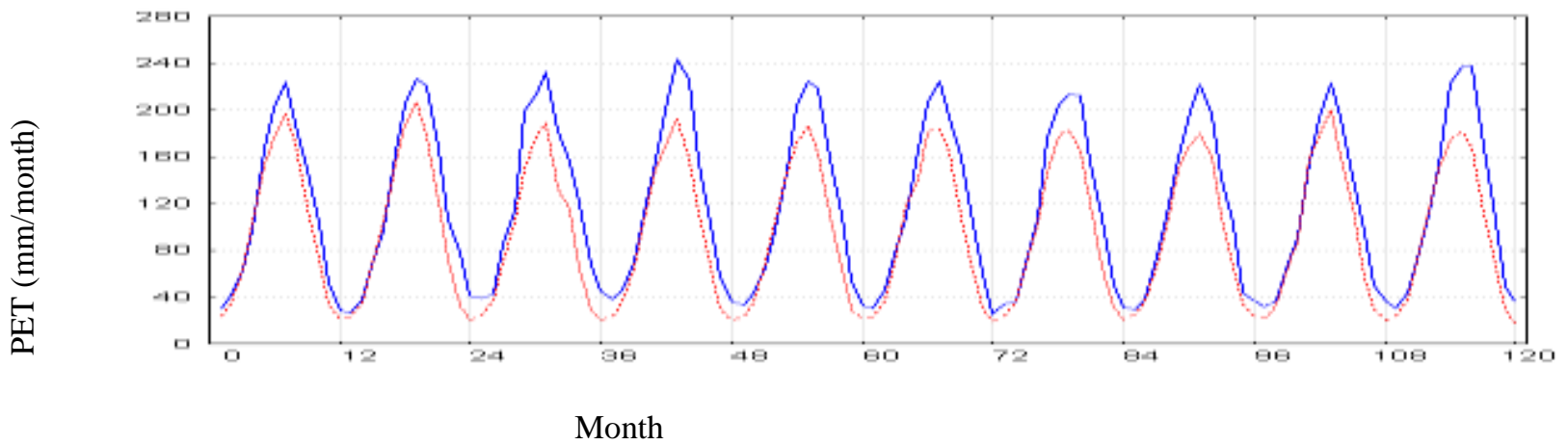

f. Priestley and Taylor versus Penman-Monteith.

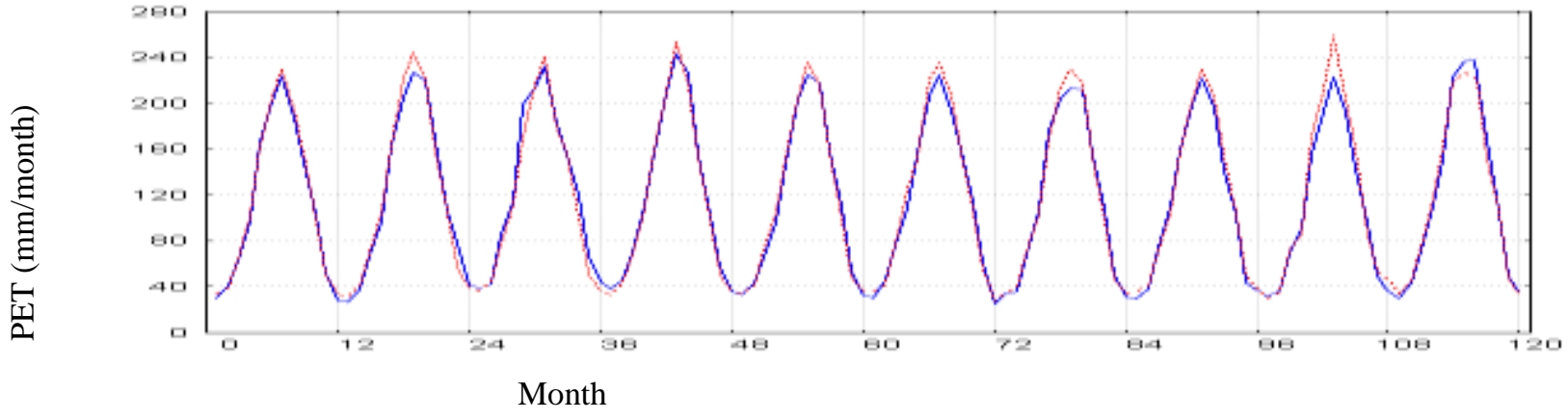

g. Hargreaves versus Penman-Monteith.

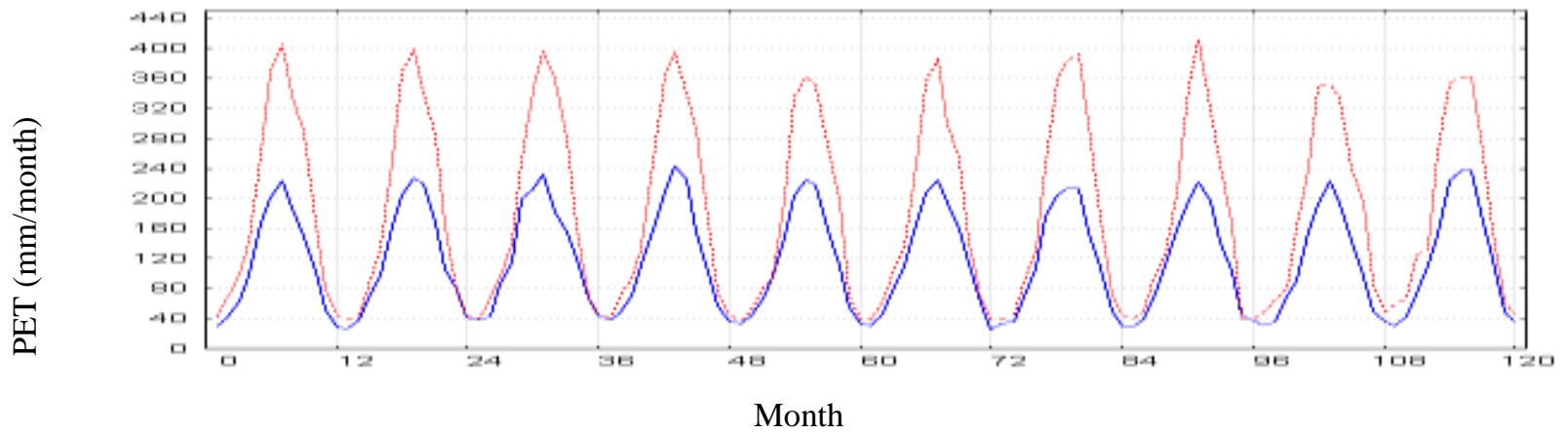

h. Pan Evaporation versus Penman-Monteith.

Fig. (2): PET over time estimated with Penman-Monteith method (dark lines) and with each of the other methods (light lines). 

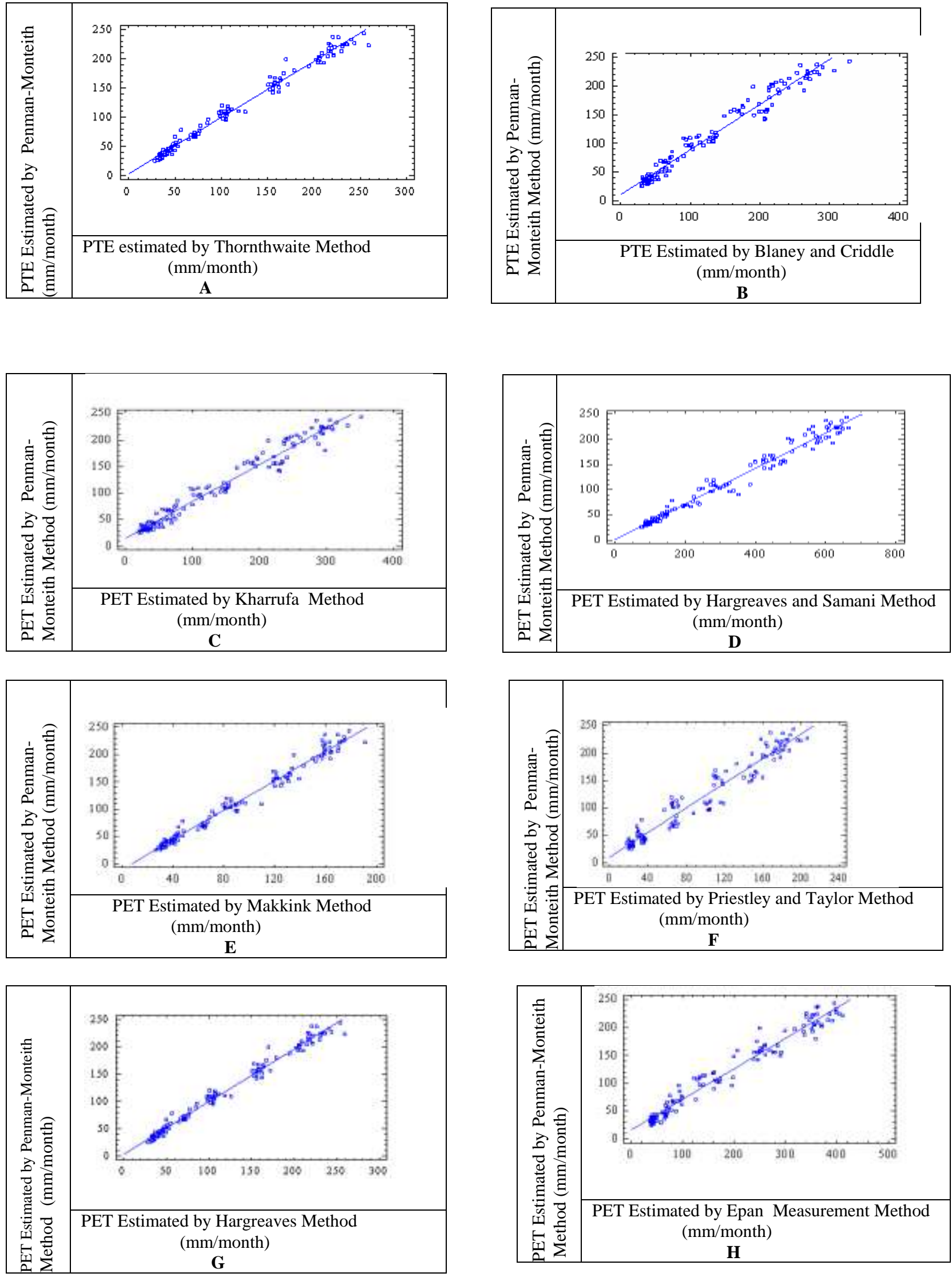

Fig. (3): The scatter diagram and linear regression line for PET estimated by Penman- Monteith method, on one hand, and PET estimated by each of the other methods, on the other hand. 
Table (4): Original and calibrated equations of each method.

\begin{tabular}{|c|c|c|}
\hline Method & Original Equation & Calibrated Equation \\
\hline Thornthwaite & $\mathrm{PET}=16^{*} \mathrm{~d}(10 \mathrm{~T} / \mathrm{I})^{\mathrm{a}}$ & $\begin{array}{c}\mathrm{PET}=30.5+17.456 \mathrm{~d} \\
\left(10 \mathrm{~T} / \mathrm{I}^{\mathrm{a}}\right.\end{array}$ \\
\hline Blaney- Criddle & $\mathrm{PET}=\mathrm{KP}(0.46 \mathrm{~T}+8.13)$. & $\mathrm{PET}=10.4+\mathrm{KP}(0.363 \mathrm{~T}+$ \\
\hline Kharrufa & $\mathrm{PET}=0.34 \mathrm{PT}^{1.3}$ & $\mathrm{PET}=15.6+0.235 \mathrm{PT}^{1.3}$ \\
\hline $\begin{array}{l}\text { Hargreaves- } \\
\text { Samani }\end{array}$ & $\begin{array}{c}\text { PET }=0.0023(\mathrm{~T}+17.8) \\
\sqrt{ }(\mathrm{Tmax} .-\mathrm{Tmin} .) \mathrm{Ra}\end{array}$ & $\begin{array}{c}\text { PET }=1.1+0.000812 \\
(\mathrm{~T}+17.8) \\
\sqrt{ }(\mathrm{Tmax} .-\mathrm{Tmin} .) \mathrm{Ra}\end{array}$ \\
\hline Makkink & $\begin{array}{c}\mathrm{PET}=0.61(\Delta / \Delta+\gamma)^{*} \\
\left(\mathrm{R}_{\mathrm{s}} / \lambda\right)\end{array}$ & $\begin{array}{c}\text { PET }=-10.4+0.825(\Delta / \Delta+ \\
\gamma) *\left(\mathrm{R}_{\mathrm{s}} / \lambda\right)\end{array}$ \\
\hline Priestle & $\begin{array}{c}\mathrm{PET}=1.26(\Delta / \Delta+\gamma) * \\
\left(\mathrm{R}_{\mathrm{n}} / \lambda\right)\end{array}$ & $\begin{aligned} \mathrm{PET}= & 10.6+1.525(\Delta / \Delta \\
& +\gamma) *\left(\mathrm{R}_{\mathrm{n}} / \lambda\right)\end{aligned}$ \\
\hline Hargre & $\begin{array}{c}\mathrm{PET}=0.0135(\mathrm{~T}+17.8) \\
\left(\mathrm{R}_{\mathrm{s}} / \lambda\right)\end{array}$ & $\begin{array}{c}\mathrm{PET}=3.5+0.013(\mathrm{~T}+ \\
17.8)\left(\mathrm{R}_{\mathrm{s}} / \lambda\right)\end{array}$ \\
\hline Pan measurement & PET $=$ Kp Epan & $\mathrm{PET}=16.8+0.546 \mathrm{kp}$ Epan \\
\hline
\end{tabular}

employed to fit linear, double log, and second degree polynomial equations. This will allow selecting the best model for each relationship. The obtained models can then be used for prediction PET estimated by PM method using corresponding data estimated by each of the other methods. Table (3) presents models coefficients and adjusted coefficient of determination $\left(\square^{2}\right)$ for each model. The table reveals high predictive capability for all methods and all models. The values of $\mathrm{R}^{2}$ ranged between 0.914 and 0.987 .

Although direct comparison between $\overline{R^{2}}$ for double log function and the other two models not valid due to the difference in the values of the dependent variables, values of $\mathrm{R}^{2}$ for double $\log$ function were lower than the corresponding values of simple linear equation and polynomial equations. In addition to that, $\overline{R^{2}}$ of simple linear equation are high enough to obtain accurate estimate. Polynomial function had $\overline{R^{2}}$ slightly better than simple linear equation for Thornwaite (1948), Blaney and Criddle(1950), Hargreaves (1975) methods, and pan evaporation measurements. The difference in the $\overline{R^{2}}$ values among the tested models for each method ranged between $0.2 \%$ and $1.2 \%$.For Priestley and Taylor method $\overline{R^{2}}$ of simple linear equation exceeded $\mathrm{R}^{2}$ of polynomial equation by $0.2 \%$. For other methods $\overline{R^{2}}$ of both functions were almost equal. Since the difference between $\overline{R^{2}}$ of simple linear equations and polynomial equations is very low, it is recommended to use simple linear equations.
Adjusted coefficient of determination of simple linear equation for the different methods ranged from 0.942 (for Priestley and Tylor method) to 0.985 (for Hargreaves method). For thermo-based methods Hargreaves and Samani method had the best performance $\left(\overline{R^{2}}=0.973\right)$, while for radiation based methods Hargreaves method was the best $\left(\overline{R^{2}}=0.985\right)$. The $\mathrm{R}^{2}$ for pan evaporation was 0.962 which also indicates high predictive capability. Therefore, any method can be used to predict PET of Penman-Monteith method. However, Hargreaves method is recommended because it had the highest predictive capability.

Table (4) presents the original and calibrated equation for each method. Depending on the availability of meteorological data, any of these calibrated equations could be used to precisely estimate PET of PM method. Although, the predictive capabilities of these methods are not equal, the differences are relatively small. Since meteorological stations may not gather all climatic data, one can use the equation with available data to precisely predict values for PET. This work was based on data for a limited area, therefore, it would be advantageous to develop equations using data that cover the entire area of the region.

\section{REFERENCES}

Ahmed Z. A. and Jasim W. E. (2002). Estimation of potential evapotranspiration by different models in Zakho Region. Journal of Dohuk University, 5, 45-48.

Alkaeed O., Flores C., Jimo K. and Tsutsumi A. (2006). Comparison of several reference 
evapotranspiration methods for Itoshima Peninsula Area, Fukuoka, Japan. Memoirs of the Faculty of Engineering, Kyushu University, Vol. 66, No.1.

Allen G. R., Jensen Marvin E., Wright James. L. and Burman Robert. D. (1989). Operational estimates of reference evapotranspiration. Agronomy Journal, 81, 650-662.

Allen G. R., Pereira L. S., Rase D. and Smith M. (1998). Crop Evapotranspiration-Guidelines for computing crop water requirements. FAO Irrigation and Drainage Paper, 56, FAO, Rome,Italy, 78-86.

Aqrawi Z. A. (2003). Hydrological and hydrogeological study of the Etot-Aloka Basin.Ph.D. Thesis, Sallahiddin University, Iraq Kurdistan Region.

Blaney H. F. and Criddle W. D.(1950). Determining water requirements in irrigated areas from climatological irrigation data.Soil Conservation Service,US Department of Agriculture,Washington, DC Tech. Paper No. 96.

Chen D., Gao G., Xu C. Y., Guo J. and Ren G. (2005). Comparison of the Thornthwaite Method and Pan Datd with the Standard Penman-Monteith estimates of reference evapotranspiration in China. Climate Research, 28, 123-132.

Currie D. J. (1991). Energy and large-scale patterns of animal-and plant-species richness. The American Naturalist, 137, 27 49.

Feder C. A.,Vorosmarty C. and Fekete B. (1996). Intercomparison of methods for calculating potential evaporation in regional and global water balance models. Water Resources Research 32, 2315-2321.

Grismer M. E., Orange M., Snyder R. and Matyac R. (2002). Pan evaporation to reference evapotranspiration conversion methods. Journal of Irrigation and Drainage .Engineering, 128, 180-184.

Hargreaves G. H.(1975). Moisture availability and crop production. Trans. ASAE. 18, 980984.

Hargreaves G. H. and Samani Z. A. (1985). Reference crop evapotranspiration from temperature. Applied Engineering Agric, 1, 96-99.

Hay L. E. and McCabe G. J. (2002). Spatial

variability in water balance model performance in the onterminous United States. Journal of the American Water Resources Association
(JAWAR), 38, 847-860.

Irmak S., Irmak A., All en, R.G. and Jones J. W. (2003). Solar and net radiation-based equations to estimate reference evapotranspiration in humid climates. Journal of Irrigation and Drainage Engineering ASCE, 129, 336-347.

Jensen M. E., Burman R. D. and Allen R. G. (1990). Evapotranspiration and irrigation water requirements, American Society of civil Engineers, New York 332p.

Kettaneh M. S. (1974). Quantitative analysis of potential evapotranspiration and free surface water evaporation from available meteorological data in Iraq, Tech. Bull. No. 63, IARNR, Jadirigh, Baghdad-Iraq. p41.

Kharrufa N. S. (1985). Simplified equation for evapotranspiration in arid region. Beitrage Zur Hydrology, Sonderheft 5.1, Kirchzarten, S: 39-47.

Kite G. (2000). Using a Basin-Scale hydrological model to estimate crop transpiration and soil evaporation, Journal of Hydrology, 229, 59-69.

Lu J., Sun G., Mc S.G. and Amatya D. M. (2005). A Comparison of six potential evapotranspiration methods for regional use in the Southeastern United States. Journal of the American Water Resources Association (JAWRA), 41, 621-633.

Makkink G. F. (1957). Testing the Penman formula by means of lysimeters. Journal of Institute of Water Eng, 11, 277-288.

Priestly C. H. B. and Taylor R. J. (1972). On the Assessment of surface heat flux and evaporation using large scale parameters. Mon. Weath. Rev, 100, 81-92.

SAS Institute (1989). SAS user's guide: statistics. Version 6.03 SAS Inst., Cary, NC.

Temesgen B. Asce S. E. M., Davidoff B. and Frame K. (2005). Comparison of some reference evapotranspiration equations for California. Journal of Irrigation and Drainage Engineering, Vol. 131, No.1, February.

Thornthwaite C. W. (1948). An approach toward a rational classification of climate. Geograph. Rev., 38, 55-94.

Wu. I.(1997). A simple evapotranspiration method for Hawaii, the Hargreaves method; Engineer's Notebook 106. College of Tropical Agriculture and Human Resources (CTAHR) Fact Sheet, 1-2. 
مقارنة بين بعض الطرائق المستخدمة في تقدير التبخر- النتح الممكن (الكامن)

في منطقة سيميل إقليم كردستان العراق التخ

محم خالد حسن - جعر تحمد طاهر حامد _* صالح خليل عبدالكريم

قسم الغابات ـ * قسم العلوم الأساسية - جامعة دهوك - إقليم كردستان - العراق

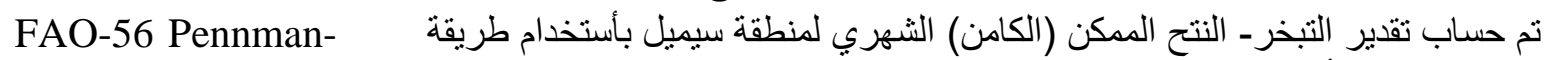

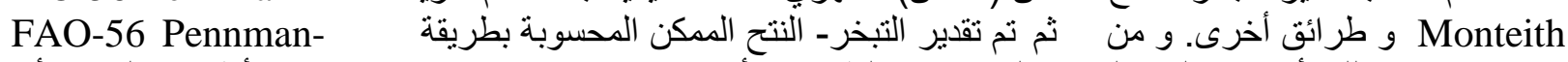
و ذللك بأستخدام النتح المكن المستخرج بالطر ائق الأخرى مستخدمين ثلاثة نماذج الفير رياضية.

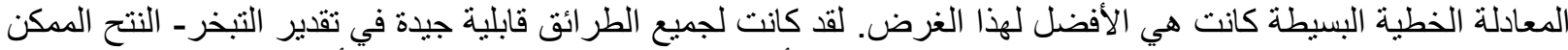
المحسوبة بطريقة FAO-56 Pennman- Monteith غير أن طريقة Hargreaves كانت الطية الأفضل من بينها.

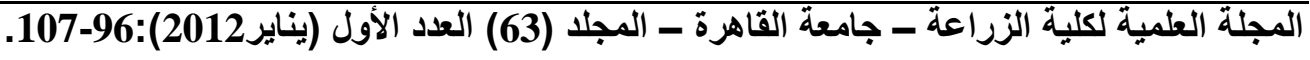

